\title{
TIJUCA NATIONAL PARK: TWO PIONEERING RESTORATIONIST INITIATIVES IN ATLANTIC FOREST IN SOUTHEASTERN BRAZIL
}

\author{
FREITAS, S. R., NEVES, C. L. and CHERNICHARO, P. \\ Laboratório de Vertebrados, Departamento de Ecologia, Universidade Federal do Rio de Janeiro, \\ C. P. 68020, CEP 21941-590, Rio de Janeiro, RJ, Brazil \\ Correspondence to: Simone R. Freitas, Laboratório de Vertebrados, Departamento de Ecologia, \\ Universidade Federal do Rio de Janeiro, C. P. 68020, CEP 21941-590, \\ Rio de Janeiro, RJ, Brazil, e-mail: sfreitas@ biologia.ufrj.br \\ Received August 8, 2004 - Accepted March 9, 2005 - Distributed November 1, 2006
}

(With 1 figure)

\begin{abstract}
As a contribution to the environmental history of the Tijuca National Park, we report on two pioneering restorationist initiatives and list its the mammal species now found in this urban park. The Tijuca National Park (TNP), a 3,200 ha urban park covered by secondary tropical forest, is located within Rio de Janeiro, in southeastern Brazil. The two restorationist initiatives were a pioneer tropical forest restoration project in the nineteenth century and a fauna management project in the 70' $\mathrm{s}$. The mammal list presented here was based on specimens in the Museu Nacional do Rio de Janeiro and on publications. The mammal community of TNP is composed of 49 species, of which 11 are on regional red lists, and four are on the 2003 IUCN Red List of Threatened Species. Occurrence of these threatened species and the park history itself made the TNP a priority site for studying conservation, management, and monitoring. Besides maintaining fauna and flora (including threatened species) diversity, the park benefits the population of Rio de Janeiro by providing water, green areas, and recreational and touristic opportunities.
\end{abstract}

Keywords: environmental history, conservation, mammals, tropical forest, urban park.

\section{RESUMO}

\section{Parque Nacional da Tijuca: Palco de duas iniciativas clássicas de restauração da Mata Atlântica no Sudeste do Brasil}

Estudos sobre monitoramento, regeneração florestal e manejo de fauna devem usar a história ambiental como referência para compreender o passado da área de estudo e para monitorar os resultados desses estudos. Para criar a base da história ambiental para o Parque Nacional da Tijuca, relatamos duas iniciativas clássicas de restauração e a lista das espécies de mamíferos que ocorrem atualmente neste parque urbano, que depende dessas iniciativas. O Parque Nacional da Tijuca (PNT) é um parque urbano de 3.200 ha coberto por floresta tropical secundária e cercado pela cidade do Rio de Janeiro, no Sudeste do Brasil. No PNT, ocorreram duas iniciativas clássicas de restauração: a pioneira restauração da floresta tropical no século XIX e o projeto de manejo da fauna nos anos 70. A lista de mamíferos foi baseada em publicações e nos espécimens depositados no Museu Nacional do Rio de Janeiro. A comunidade de mamíferos do PNT é composta por 49 espécies, sendo 11 incluídas nas listas vermelhas regionais e quatro espécies na Lista Vermelha de Espécies Ameaçadas da IUCN de 2003. A ocorrência dessas espécies ameaçadas e a história do parque tornaram o Parque Nacional da Tijuca uma área de estudo prioritária para monitoramento, conservação e manejo. Além do PNT ser um parque urbano importante para a manutenção da diversidade da fauna e da flora, incluindo as espécies ameaçadas, também melhora a qualidade de vida da população da cidade do Rio de Janeiro, fornecendo áreas verdes, recreação, turismo e abastecimento de água. Concluindo, enfatizamos a grande importância da história ambiental no Parque Nacional da Tijuca para a composição atual da comunidade de mamíferos.

Palavras-chave: história ambiental, conservação, mamíferos, floresta tropical, parque urbano. 


\section{INTRODUCTION}

Historical ecology encompasses all data, techniques, and perspectives derived from paleoecology; land use history, based on archival and documentary research; and long-term ecological research, involving monitoring and experiments extending over decades (Swetnam et al., 1999). However, studies of this type are few with respect to tropical forests. The general lack of historical data about such regions makes studies of their environmental history unusually challenging. In addition, the results of such research on a regional or global scale increases our appreciation of the dynamic nature of landscapes, and provides a frame of reference within which to examine changing patterns and processes (Simmons, 1993; Dean, 1996; Swetnam et al., 1999).

In Brazil, monitoring studies have resulted in experimental designs and development of improved methodologies appropriate to local characteristics, in addition to which forest regeneration initiatives have been carried out (Garay \& Dias, 2001; Cullen Jr. et al., 2003; Parrotta \& Knowles, 1999; Almeida, 2000; Primack \& Rodrigues, 2001; Camargo et al., 2002; Kageyama \& Gandara, 2003). Moreover, various projects exist on fauna reintroduction and management of the tamarins Leontopithecus chrysopygus (Callitrichidae, Primates) in Parque Estadual do Morro do Diabo (São Paulo State), and Leontopithecus rosalia in Reserva Biológica de Poço das Antas and Reserva Biológica União (Rio de Janeiro State) (Primack \& Rodrigues, 2001; Fernandez et al., 2003). All of these projects and studies may gain perspective through a knowledge of environmental history as related to particular study sites.

As a contribution to the environmental history of the Tijuca National Park, we here report on two pioneering restorationist initiatives and list the mammal species currently found within the park, and which may be part of the long-term results of these initiatives.

\section{STUDY SITE}

The Tijuca National Park (TNP) is located in the middle of Rio de Janeiro $\left(22^{\circ} 55^{\prime}-22^{\circ} 00^{\prime} \mathrm{S}\right.$ and $43^{\circ} 11^{\prime}-43^{\circ} 19^{\prime} \mathrm{W}$ ) in the Maciço da Tijuca Mountains, southeastern Brazil (IBDF, 1981) (Fig. 1). One of the world's largest (3,200 ha) urban parks, TNP is divided into three subunits delimited in 1967: Tijuca Forest, Serra da Carioca, and Pedra da Gávea/Pedra Bonita (IBDF, 1981), and is of high

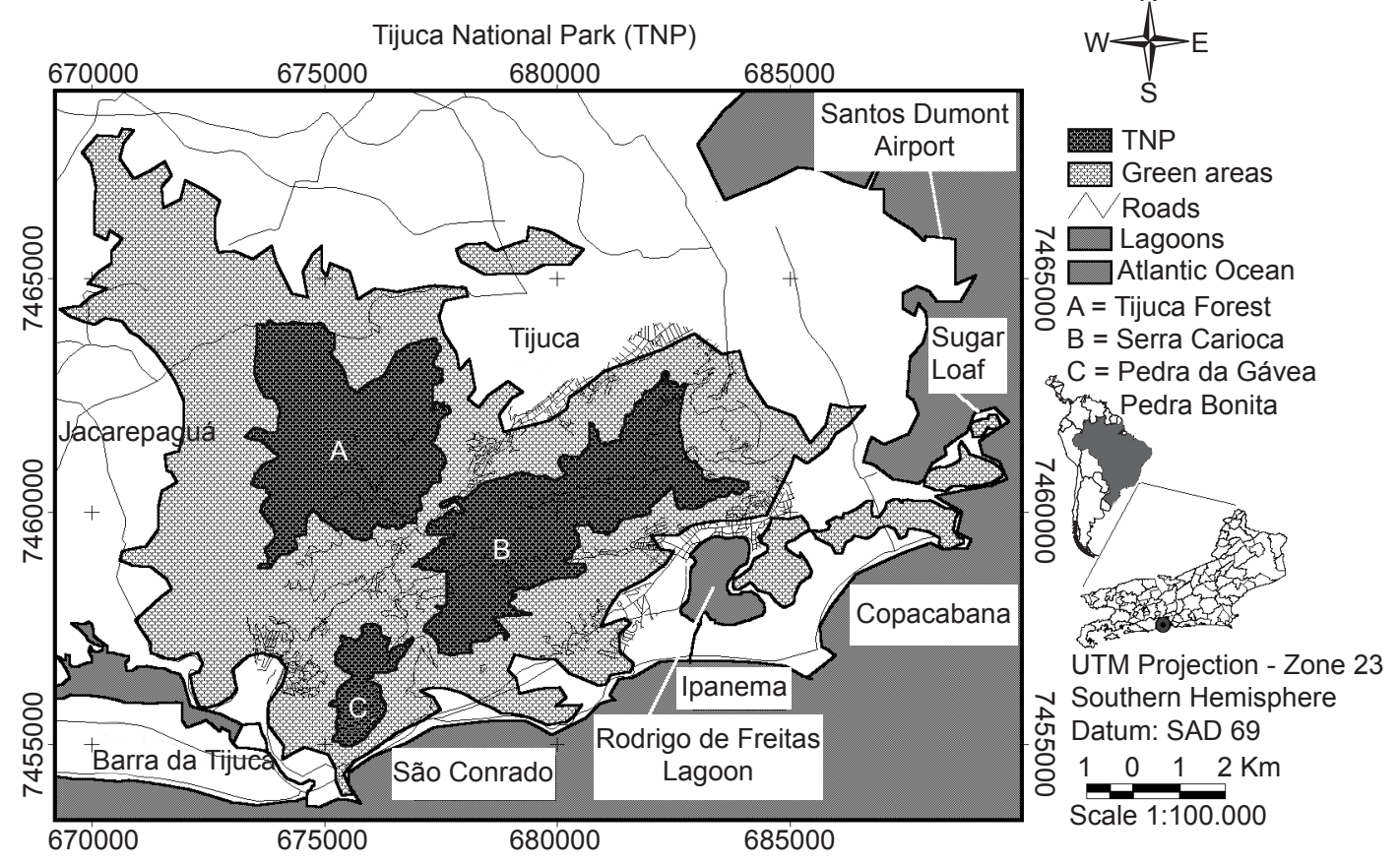

Fig. 1 - Location of Tijuca National Park. 
biological importance for conservation of Atlantic forest and its fauna, particularly reptiles, birds, and mammals (Brasil, 2000).

The climate is tropical with rainy summers and dry winters. A thermal gradient of $0.4^{\circ} \mathrm{C} / 100 \mathrm{~m}$ was calculated for temperature variation with altitude (80 $\mathrm{m}$ to $1,021 \mathrm{~m}$ ) (Mattos et al., 1976). Below $500 \mathrm{~m}$ high, precipitation exceeds 2,000 mm yearly, mean temperature of the warmest month is above $22{ }^{\circ} \mathrm{C}$, and that of the coldest is higher than $18{ }^{\circ} \mathrm{C}$. At areas above $500 \mathrm{~m}$, precipitation is similar and mean temperature of the coldest month is less than $18{ }^{\circ} \mathrm{C}$ (Mattos et al., 1976). The TNP vegetation is typical of tropical rain forest, characterized by big trees, palms, ferns, epiphytes, and lianas. The more frequent plant families are Leguminosae, Sapotaceae, Bombacaceae, Euphorbiaceae, Meliaceae, Lauraceae, Lecythidaceae, Moraceae, and Melastomataceae (CCN, 1966).

\section{PIONEERING TROPICAL FOREST RESTORATION IN BRAZIL}

From the sixteenth to the nineteenth centuries, tropical forest in Rio de Janeiro was gradually substituted by sugarcane, coffee plantations, and pastureland (Dean, 1996; Amador, 1997). Intense land use and deforestation caused problems in the city's water supply (CCN, 1966; Castro Maya, 1967; Scheiner, 1976; Drummond, 1988). Mainly for this reason, Manuel Gomes Archer was hired at the end of the nineteenth century by Emperor D. Pedro II to start a flora restoration project (Scheiner, 1976; Dean, 1996; Amador, 1997; Drummond, 1997; Pádua, 2002). From 1862 to 1874 , Archer and a few slaves planted about 72,000 seedlings of native and exotic tree species, e.g., palms, bamboos, cedro rosa (Cedrela fissilis), jacaranda (Machaerium sp.), sapucaia (Lecythis pisonis), jaqueira (Artocarpus integrifolia), and eucaliptus (Eucalyptus spp.) (CCN, 1966; Drummond, 1997). Seedling sources were located in the Paineiras Forest, Archer's farm in Guaratiba, and in the Botanical Garden of Rio de Janeiro. This reforestation project of Archer did not include the whole of what is presently Tijuca National Park; however in the area within the original project and which then became part of TNP, the result was an environment conducive to natural forest regeneration (Drummond, 1988;
Coimbra-Filho et al., 1973; Dean, 1996). This was because heterogeneous and predominantly native species of trees were used in this project, unlike the procedure usually followed in forest plantation at that time (Drummond, 1988).

Subsequently, Archer's successor, Gastão Luís Henrique D'Escragnolle concentrated on park infrastructure, which resulted in turning Tijuca Forest into an area appropriate for public recreation (Drummond, 1988).

In 1861, the first conservation area in Brazil was established in Tijuca Forest and Paineiras (BRASIL, 1998). In 1961, to protect the water reservoir of Rio de Janeiro, this area became the Tijuca National Park (Scheiner, 1976; Drummond, 1997; BRASIL, 1998).

\section{THE SECOND RESTORATION PROJECT: FAUNA}

In the nineteen-seventies, Adelmar CoimbraFilho and Antonio Aldrighi and their group began a fauna restoration project in Tijuca National Park, in the course of which an imbalance in populations of some species was observed. For instance, the marmoset Callithrix jacchus (Callitrichidae, Primates), an introduced species from the Brazilian northeast, reproduced so quickly that bird populations were being threatened because of egg predation (Coimbra-Filho \& Aldrighi, 1971). Their project consisted of recovering reptiles, birds, and mammals; cultivating plant species (such as bromeliads and orchids) present in the diet of these fauna; reintroducing vanished species; and controlling predator populations and hunters (Coimbra-Filho \& Aldrighi, 1971). The species chosen fit criteria specifying (1) a population compatible with, and having a home range smaller than, the area of Tijuca National Park; (2) habits not conducive to soil erosion; and (3) being a seed dispersor or a prey of rare predators (CoimbraFilho \& Aldrighi, 1971; Coimbra-Filho \& Aldrighi, 1972; Coimbra-Filho et al., 1973).

From 1969 to 1973 , the fauna restoration project reintroduced one reptile species (Boa constrictor), 25 bird species, and 7 mammal species (Table 1). The group of Coimbra-Filho and Aldrighi introduced five snakes, 914 birds, and 58 mammals that had been captured by hunters in other forests of Rio de Janeiro State (Coimbra- 
TABLE 1

Number of individuals (reptiles, birds, and mammals) introduced into the Tijuca National Park from 1969 to 1973.

\begin{tabular}{|c|c|c|c|c|}
\hline Classes & Orders & Families & Species & $\begin{array}{c}\text { Number of introduced } \\
\text { individuals }\end{array}$ \\
\hline Reptilia & Squamata & Boidae & Boa constrictor & 5 \\
\hline Aves & Tinamiformes & Tinamidae & Crypturellus tataupa & 19 \\
\hline Aves & Galliformes & Cracidae & Penelope superciliaris & 5 \\
\hline Aves & Galliformes & Phasianidae & Odontophorus capueira & 8 \\
\hline Aves & Columbiformes & Columbidae & Leptotila rufaxila & 13 \\
\hline Aves & Psittaciformes & Psittacidae & Brotogeris tirica & 34 \\
\hline Aves & Psittaciformes & Psittacidae & Pionopsitta pileata & 2 \\
\hline Aves & Psittaciformes & Psittacidae & Pyrrhura cruentata & 66 \\
\hline Aves & Psittaciformes & Psittacidae & Pyrrhura frontalis & 42 \\
\hline Aves & Psittaciformes & Psittacidae & Pyrrhura leucotis & 95 \\
\hline Aves & Piciformes & Ramphastidae & Baillonius bailloni & 26 \\
\hline Aves & Piciformes & Ramphastidae & Ramphastos vitellinus & 47 \\
\hline Aves & Piciformes & Picidae & Melanerpes flavifrons & 14 \\
\hline Aves & Passeriformes & Cotingidae & Procnias nudicollis & 12 \\
\hline Aves & Passeriformes & Muscicapidae & Platycichla flavipes & 20 \\
\hline Aves & Passeriformes & Muscicapidae & Turdus rufiventris & 19 \\
\hline Aves & Passeriformes & Emberizidae & Cacicus haemorrhous & 40 \\
\hline Aves & Passeriformes & Emberizidae & Coryphospingus pileatus & 29 \\
\hline Aves & Passeriformes & Emberizidae & Euphonia violacea & 30 \\
\hline Aves & Passeriformes & Emberizidae & Euphonia xanthogaster & 30 \\
\hline Aves & Passeriformes & Emberizidae & Icterus cayanensis & 46 \\
\hline Aves & Passeriformes & Emberizidae & Saltator maximus & 2 \\
\hline Aves & Passeriformes & Emberizidae & Saltator similis & 171 \\
\hline Aves & Passeriformes & Emberizidae & Tangara cyanocephala & 55 \\
\hline Aves & Passeriformes & Emberizidae & Tangara seledon & 86 \\
\hline Aves & Passeriformes & Emberizidae & Thraupis sayaca & 3 \\
\hline Mammalia & Xenarthra & Myrmecophagidae & Tamandua tetradactyla & 4 \\
\hline Mammalia & Xenarthra & Bradypodidae & Bradypus torquatus & 11 \\
\hline Mammalia & Xenarthra & Bradypodidae & Bradypus variegatus & 14 \\
\hline Mammalia & Xenarthra & Dasypodidae & Dasypus novemcinctus & 1 \\
\hline Mammalia & Rodentia & Sciuridae & Sciurus aestuans & 2 \\
\hline Mammalia & Rodentia & Dasyproctidae & Dasyprocta leporina & 25 \\
\hline Mammalia & Artiodactyla & Cervidae & Mazama americana & 1 \\
\hline
\end{tabular}

Filho et al., 1973) by foresters (Instituto Brasileiro de Desenvolvimento Florestal). As result of this project, Coimbra-Filho et al. (1973) discovered the rodent Dasyprocta leporina, the existence of which in TNP had until then been unrecorded. Other successful reintroductions by Coimbra's group included the sloth Bradypus torquatus and the birds Crypturellus tataupa, Pyrrhura cruentata, Pyrrhura frontalis, Pyrrhura leucotis, Baillonius bailloni, Ramphastus vitellinus, Euphonia violacea, Euphonia xanthogaster, and Tangara cyanocephala. Coimbra-Filho (2000) recorded the recovery of the toucan Ramphastus vitellinus 30 years after the project's implantation.

But Coimbra's group also experienced some setbacks: the species Cacicus haemorrhous and Icterus cayanensis were not subsequently found (Coimbra-Filho et al., 1973). In commenting on 
these results, they cited lack of control measures against hunters and ornamental plant collectors.

\section{UPDATED RESULTS OF BOTH PROJECTS}

The project of Archer and the Aldrighi and Coimbra Filho group were pioneering and ambitious, and resulted in one of the world's largest urban parks, which is singular in being covered by secondary tropical forest and modified by high occurrence of exotic species (Drummond, 1997). Aldrighi and Coimbra Filho's species introduction project introduced, sometimes successfully, various species. Together, these projects have promoted in TNP a process of succession into mature forest (Oliveira, 2002) in which many vertebrate species now are found as a result of introduction or migration. This study presents in tables 1 and 2 a list of these species, which is based in part on studies (Coimbra-Filho \& Aldrighi, 1971; CoimbraFilho \& Aldrighi, 1972; Coimbra-Filho et al., 1973; Bueno, 1998; Esbérard, 1999) and in part on specimens the data for which was recorded from 1940 to 1999 and is now in the Museu Nacional do Rio de Janeiro. Records show the presence of 8 species of Didelphimorphia, 3 of Xenarthra, 25 of Chiroptera, 3 of Primates, 4 of Carnivora, and 6 of Rodentia (Table 2) in Tijuca National Park. Of these 49 species, 7 are classified as threatened and are included on the red list of the Municipality of Rio de Janeiro (Conde et al., 2000), 7 species are on the red list of Rio de Janeiro State (Bergallo et al., 2000), 2 are on the Brazilian red list (Brasil, 2003) and 4 are on the 2003 IUCN Red List of Threatened Species (IUCN, 2003a).

Leopardus wiedii and Myotis ruber were on all three regional red lists, whereas Monodelphis aff. theresa, Caluromys philander, Chironectes minimus, and Monodelphis americana were included in 2003 IUCN Red List (Table 2). The occurrence of these threatened species within this park has made the Tijuca National Park a prioritized site for studying conservation and management of tropical Atlantic forest. We suggest further studies to evaluate vulnerability of vertebrate species populations. Another topic for study is possible effects of exotic plant species on native ones, e.g., between jaqueira (Artocarpus integrifolia) and seedlings of native species, which may impede the successional process.

\section{THE IMPORTANCE OF TIJUCA NATIONAL PARK}

Besides TNP being an important urban park because it maintains fauna and flora diversity, which includes threatened species, this park also contributes to the well-being of Rio de Janeiro's population of almost six million people (IBGE, 2003). Coles \& Bussey (2000) advocated that, to benefit human neighborhoods, woodlands should be within a 5-10 min walking distance of residences, of a size natural to woodland environments (a 2 ha minimum), and older than 25 years. The Tijuca National Park meets this description and is, therefore, a significant tourist attraction (Drummond, 1997). Moreover, the park is a source of the city's water supply and has one of its lowest air-pollution levels because of reduced traffic density and effects of the wind patterns and abundant vegetation (Barcellos et al., 1998; Azevedo et al., 1999).

\section{CONCLUSION}

The restorationist projects of both Archer and Coimbra-Filho and his group are of historical importance, since they ultimately resulted in making Tijuca National Park into one of the world's largest urban parks.

While some of the techniques and methods previously used are now outdated and been replaced by others, their effects carry over until the present time, and they are part of the historical framework in which to view modern projects having the same aim (Almeida, 2000; Primack \& Rodrigues, 2001; IUCN, 2003b; Kageyama \& Gandara, 2003). It is hoped that in describing these two projects and their results over time, others may inspire similar projects for tropical forests of developing countries.

Finally, we stress the great relevance of Tijuca National Park's environmental history to the current mammal community composition. If no forest had been recovered through Archer's reforestation project, and Coimbra-Filho and Aldrighi had not undertaken their restoration project, it is probable that Tijuca National Park as it is today would not exist.

Acknowledgments - We would like to thank Cecília Bueno, Carlos Esbérard, Marcelo R. Nogueira, Marco Aurélio R. Mello, and Lena Geise for their support in data research, and also to Stella Maris Santos Franco for her help in supplying data on mammals from the archives of the Museu Nacional do Rio de Janeiro. We are very grateful to Ana Cristina P. 
TABLE 2

List of mammal species presently occurring in Tijuca National Park and their threat status.

\begin{tabular}{|c|c|c|c|c|c|}
\hline Orders & Species & MRJ & SRJ & $\mathbf{B R}$ & IUCN \\
\hline \multirow[t]{8}{*}{ Didelphimorphia } & Caluromys philander & & & & $\mathrm{LR} / \mathrm{nt}$ \\
\hline & Chironectes minimus & & ST & & $\mathrm{LR} / \mathrm{nt}$ \\
\hline & Didelphis aurita & & & & \\
\hline & Metachirus nudicaudatus & & & & \\
\hline & Micoureus demerarae & & & & \\
\hline & Monodelphis americana & & & & $\mathrm{LR} / \mathrm{nt}$ \\
\hline & Monodelphis aff. theresa & & PEX & & VU/A1c \\
\hline & Philander frenatus & & & & \\
\hline \multirow[t]{3}{*}{ Xenarthra } & Bradypus variegatus & VU & & & \\
\hline & Tamandua tetradactyla & VU & & & \\
\hline & Dasypus novemcinctus & & & & \\
\hline \multirow[t]{25}{*}{ Chiroptera } & Anoura caudifer & & & & \\
\hline & Artibeus cinereus & & VU & & \\
\hline & Artibeus fimbriatus & & & & \\
\hline & Artibeus jamaicensis & & & & \\
\hline & Artibeus lituratus & & & & \\
\hline & Artibeus obscurus & & & & \\
\hline & Carollia perspicillata & & & & \\
\hline & Chiroderma doriae & VU & VU & & \\
\hline & Desmodus rotundus & & & & \\
\hline & Diphylla ecaudata & & & & \\
\hline & Eptesicus brasiliensis & & & & \\
\hline & Eumops auripendulus & & & & \\
\hline & Glossophaga soricina & & & & \\
\hline & Histiotus velatus & & & & \\
\hline & Lasiurus borealis & & & & \\
\hline & Lonchophylla mordax & & & & \\
\hline & Micronycteris megalotis & & & & \\
\hline & Molossus molossus & & & & \\
\hline & Myotis nigricans & & & & \\
\hline & Myotis ruber & $\mathrm{VU}$ & $\mathrm{VU}$ & VU & \\
\hline & Platyrrhinus lineatus & & & & \\
\hline & Pygoderma bilabiatum & & & & \\
\hline & Sturnira lilium & & & & \\
\hline & Tonatia bidens & & & & \\
\hline & Vampyressa pusilla & & & & \\
\hline \multirow[t]{3}{*}{ Primates } & Callitrix jacchus & & & & \\
\hline & Cebus apella & & & & \\
\hline & Saimiri sciureus & & & & \\
\hline \multirow[t]{4}{*}{ Carnivora } & Cerdocyon thous & & & & \\
\hline & Nasua nasua & & & & \\
\hline & Procyon cancrivorus & VU & & & \\
\hline & Leopardus wiedii* & $\mathrm{CE}$ & VU & VU & \\
\hline Rodentia & Agouti paca & & $\mathrm{VU}$ & & \\
\hline \multirow[t]{5}{*}{ Rodentia } & Dasyprocta leporina & VU & & & \\
\hline & Oxymycterus dasytrichus & & & & \\
\hline & Rattus rattus & & & & \\
\hline & Sciurus aestuans & & & & \\
\hline & Sphiggurus villosus & & & & \\
\hline
\end{tabular}

*probably; MRJ = Red list of Municipality of Rio de Janeiro (Conde et al., 2000); SRJ = Red list of Rio de Janeiro State (Bergallo et al., 2000); BR = Brazilian red list (Brasil, 2003); IUCN = 2003 IUCN Red List of Threatened Species (IUCN, 2003a); PEX = Probably extinct, i.e., no records in last 30 years (Bergallo et al., 2000); CE = Critically endangered (IUCN, 1994); VU = Vulnerable (IUCN, 1994); VU/A1c = Vulnerable, i.e., population reduction whether observed, estimated, inferred, or suspected of at least $20 \%$ over the last 10 years or three generations, whichever is the longer, based on a decline in area of occupancy, extent of occurrence, and/or quality of habitat (IUCN, 1994); ST = Presumed threatened, i.e., species requiring heightened conservationist attention (Bergallo et al., 2000); and LR/nt = Lower Risk/Near Threatened (IUCN, 1994). 
Vieira, coordenadora de educação e cultura do Parque Nacional da Tijuca, for help in finding references, and to Carlos E. V. Grelle, Lena Geise, Marcus V. Vieira, and Diogo Loretto for suggestions on the manuscript. This study was supported by grants from CAPES.

\section{REFERENCES}

ALMEIDA, D. S., 2000, Recuperação ambiental da Mata Atlântica. Editus, Ilhéus, 130p.

AMADOR, E. S., 1997, Baía de Guanabara e ecossistemas periféricos: homem e natureza. E. S. Amador, Rio de Janeiro, 539p.

AZEVEDO, D. A., MOREIRA, L. S. \& SIQUEIRA, D. S., 1999, Composition of extractable organic matter in aerosols from urban areas of Rio de Janeiro city, Brazil. Atmospheric Environment, 33: 4987-5001.

BARCELLOS, C., COUTINHO, K., PINA, M. F., MAGAlHÃES, M. M. A. F., PAOLA, J. C. M. D. \& SANTOS, S. M., 1998, Inter-relacionamento de dados ambientais e de saúde: análise de risco à saúde aplicada ao abastecimento de água no Rio de Janeiro utilizando Sistemas de Informações Geográficas. Cad. Saúde Pública, 14: 597-605.

BERGAllo, H. G., ROCHA, C. F. D., ALVES, M. A. S. \& VAN SLUYS, M., 2000, A fauna ameaçada de extinção do Estado do Rio de Janeiro. EdUERJ, Rio de Janeiro, 168p.

BRASIL, 1998, Primeiro relatório nacional para a conservação sobre diversidade biológica. MMA, Brasília, 283p.

BRASIL, 2000, Avaliação e ações prioritárias para a conservação da biodiversidade da Mata Atlântica $e$ Campos Sulinos. MMA/SBF, Brasília, 40p.

BRASIL, 2003, Lista Nacional das Espécies da Fauna Brasileira Ameaçadas de Extinção. Disponível em <http:// www.mma.gov.br/port/sbf/fauna/index.cfm>. Acesso em: 26 April 2003.

BUENO, C., 1998, Conservação de biodiversidade nos parques urbanos: caso do Parque Nacional da Tijuca. Dissertação de Mestrado - Universidade Estácio de Sá, Rio de Janeiro, $153 \mathrm{p}$.

CAMARGO, J. L. C., FERRAZ, I. D. K. \& IMAKAWA, A. M., 2002, Rehabilitation of degraded areas of central Amazonia using direct sowing of forest tree seeds. Restoration Ecology, 10: 636-644.

CASTRO MAYA, R. O., 1967, A Floresta da Tijuca. Edições Bloch, Rio de Janeiro, 102p.

CCN, 1966, Floresta da Tijuca. Centro de Conservação da Natureza, Rio de Janeiro, 152p.

COIMBRA-FILHO, A. F., 2000, Reintrodução do tucano-debico-preto (Ramphastos vitellinus ariel Vigors, 1826) no Parque Nacional da Tijuca (Rio de Janeiro-RJ) e notas sobre sua distribuição geográfica. Boletim do Museu de Biologia Mello Leitão, 11/12: 189-200.

COIMBRA-FILHO, A. F., ALDRIGHI, A. D. \& MARTINS, H. F., 1973, Nova contribuição ao restabelecimento da fauna do Parque Nacional da Tijuca, GB, Brasil. Brasil Florestal, 4: 7-25.
COIMBRA-FILHO, A. F. \& ALDRIGHI, A. D., 1971, A restauração da fauna do Parque Nacional da Tijuca. Publicações Avulsas do Museu Nacional, 57: 1-30.

COIMBRA-FILHO, A. F. \& ALDRIGHI, A. D., 1972, Restabelecimento da fauna no Parque Nacional da Tijuca (Segunda Contribuição). Brasil Florestal, 3: 19-32.

COLES, R. W. \& BUSSEY, S. C., 2000, Urban forest landscapes in the UK: progressing the social agenda. Landscape and Urban Planning, 52: 181-188.

CONDE, C. F. V., BUENO, C., BONVICINO, C. R., VAZ, S. M. \& ESBÉRARD, C., 2000, Espécies nativas ameaçadas de extinção no município do Rio de Janeiro. In: Secretaria Municipal de Meio Ambiente (ed.), Espécies ameaçadas de extinção no município do Rio de Janeiro: flora e fauna, Secretaria Municipal de Meio Ambiente, Rio de Janeiro.

CULLEN JR., L., RUDRAN, R. \& VALLADARES-PADUA, C., 2003, Métodos de estudos em biologia da conservação e manejo da vida silvestre. Editora da UFPR; Fundação O Boticário de Proteção à Natureza, Curitiba, 667p.

DEAN, W., 1996, A ferro e fogo: a história e a devastação da Mata Atlântica brasileira. Companhia das Letras, São Paulo, 484p.

DRUMMOND, J. A., 1988, O jardim dentro da máquina: breve história ambiental da Floresta da Tijuca. Estudos Históricos, 1: 278-294.

DRUMMOND, J. A., 1997, Devastação e preservação ambiental: os parques nacionais do Estado do Rio de Janeiro. EdUFF, Niterói, 306p.

ESBÉRARD, C. E. L., 1999, Diversidade de Chiroptera em Unidades de Conservação do Maciço da Tijuca, Município do Rio de Janeiro, RJ. Dissertação de Mestrado - Universidade Federal Rural do Rio de Janeiro, Rio de Janeiro, 76p.

FERNANDEZ, F. A. S., ALMEIDA, E. A. B., CULLEN Jr., L., MARTINS, C. S., OLIVEIRA, P. P., VALLADARESPADUA, C., RAMBALDI, D. M., SCARIOT, A., SILVEIRA, F. A., VIDIGAL, T. H. D. A. \& VIEIRA, D. L. M., 2003, Manejo das populações naturais nos fragmentos. In: D. M. Rambaldi \& D. A. S. Oliveira (eds.), Fragmentação de ecossistemas: causas, efeitos sobre a biodiversidade e recomendações de políticas públicas, MMA/SBF, Brasília.

GARAY, I. \& DIAS, B., 2001, Conservação da biodiversidade em ecossistemas tropicais: avanços conceituais e revisão de novas metodologias de avaliação e monitoramento. Editora Vozes, Petrópolis, 430p.

IBDF, 1981, Plano de Manejo: Parque Nacional da Tijuca. Doc. Técnico no 11. Instituto Brasileiro de Desenvolvimento Florestal, Brasília,

IBGE, 2003, Cidadesat. Disponível em <http://www.ibge.gov. br/cidadesat/default.php>. Acesso em: 5 April 2004.

IUCN, 1994, 1994 IUCN Red List Categories and Criteria. Disponível em <http://www.redlist.org/info/categories_ criteria1994.html>. Acesso em: 5 April 2004.

IUCN, 2003a, 2003 IUCN Red List of Threatened Species. Disponível em <www.redlist.org>. Acesso em: 5 April 2004. 
IUCN, 2003b, IUCN/SSC Guidelines For Re-Introductions. Disponível em <http://www.iucn.org/themes/ssc/pubs/ policy/reinte.htm\#One>. Acesso em: 5 April 2004.

KAGEYAMA, P. \& GANDARA, F. B., 2003, Restauração e conservação de ecossistemas tropicais. In: L. Cullen Jr., R. Rudran \& C. Valladares-Padua (eds.), Métodos de estudos em biologia da conservação e manejo da vida silvestre, Editora da UFPR; Fundação O Boticário de Proteção à Natureza, Curitiba.

MATTOS, C. C. L. V., MATTOS, M. D. L. \& LAROCHE, R. C., 1976, Aspectos do clima e da flora do Parque Nacional da Tijuca. Brasil Florestal, 7: 3-12.

OLIVEIRA, R. R., 2002, Ação antrópica e resultantes sobre a estrutura e composição da Mata Atlântica na Ilha Grande, RJ. Rodriguésia, 53: 33-58.
PÁDUA, J. A., 2002, Um sopro de destruição: pensamento político e crítica ambiental no Brasil escravista (17861888). Jorge Zahar Editora, Rio de Janeiro, 318p.

PARROTTA, J. A. \& KNOWLES, O. H., 1999, Restoration of tropical moist forests on bauxite-mined lands in the Brazilian Amazon. Restoration Ecology, 7: 103-116.

PRIMACK, R. B. \& RODRIGUES, E., 2001, Biologia da conservação. E. Rodrigues, Londrina, 328p.

SCHEINER, T. C. H., 1976, Ocupação humana no Parque Nacional da Tijuca: aspectos gerais. Brasil Florestal, 7: 3-27.

SIMMONS, IG, 1993, Environmental history: a concise introduction. Blackwell, Oxford, 206p.

SWETNAM, T. W., ALLEN, C. D. \& BETANCOURT, J. L., 1999, Applied historical ecology: using the past to manage for the future. Ecological Applications, 9: 1189-1206. 